\title{
33. ORIENTATION OF IN SITU STRESSES IN THE PACIFIC PLATE: DEEP SEA DRILLING PROJECT HOLE 597C 1
}

\author{
Robin L. Newmark, Lamont-Doherty Geological Observatory and Department of Geological Sciences, \\ Columbia University \\ Roger N. Anderson, Lamont-Doherty Geological Observatory, Columbia University \\ and \\ Mark D. Zoback, U.S. Geological Survey, Menlo Park²
}

\begin{abstract}
The analysis of borehole televiewer records from DSDP Hole 597C has provided an estimate of the orientation of the near-surface horizontal principal stresses at a site in the oceanic crust about $1800 \mathrm{~km}$ west of the East Pacific Rise at $19^{\circ} \mathrm{S}$. The televiewer data reveal wellbore breakouts with a consistent orientation of $\mathrm{N} 31 \mathrm{E} \pm 25^{\circ}$. This orientation indicates an average maximum horizontal compression direction of N121E magnetic, which, when corrected for magnetic declination at the site, results in a maximum horizontal compression direction of $\mathrm{N} 110 \mathrm{E} \pm 25^{\circ}$. This direction is parallel to both the relative and absolute motion vectors for the Pacific Plate. It is also parallel to the orientation of the P axes of focal mechanism solutions of intraplate earthquakes located near the site, and it is consistent with an interpretation of a dominant ridge-push force acting at the site.
\end{abstract}

\section{INTRODUCTION}

In this study, borehole breakouts are used as indicators of the orientation of horizontal principal stresses. Breakouts are borehole elongations caused by preferential spalling in the zones where the circumferential compressive stress is greatest (Bell and Gough, 1979 and 1982; Gouglı and Bell, 1981 and 1982; Zoback et al., 1985), and in which the average azimuth of the long dimension is consistent in a given well or field (Cox, 1970; Babcock, 1978). Stress-induced wellbore breakouts form at an azimuth perpendicular to the maximum horizontal principal stress direction (Zoback et al., 1985). A number of authors have described wellbore breakouts and reported their occurrence in wells from several parts of North America (Cox, 1970; Babcock, 1978; Schafer, 1980; Brown et al., 1980; Gough and Bell, 1981 and 1982; Springer and Thorpe, 1981; Bell and Gough, 1979 and 1982; Plumb, 1982; Hickman et al., 1982; Seeburger and Zoback, 1982; Gough et al., 1983; Fordjor et al., 1983) and in the oceanic crust (Zoback and Anderson, 1982; Newmark et al., 1984, 1985). They have also reported problems in properly identifying these breakouts (e.g., Blumling et al., 1983). There now seems to be ample evidence that breakouts can be used as a reliable indicator of the orientation of the horizontal principal stresses. In this chapter, we use specially processed data from a borehole televiewer (BHTV) (Fig. 1) and the method of study used by Zoback et al. (1985) to examine the detailed shape of breakouts.

\footnotetext{
${ }^{1}$ Leinen, M., Rea, D. K., et al., Init. Repts. DSDP, 92: Washington (U.S. Govt. Printing Office). Lamont-Doherty Geological Observatory Contribution No. 3954.

2 Addresses: (Newmark, present address) Lawrence Livermore National Laboratory, Livermore, CA 94550; (Anderson) Borehole Research Group, Lamont-Doherty Geological Observatory, Columbia University, Palisades, NY 10964; (Zoback, present address) Department of Geophysics, Stanford University, Stanford, CA 94305.
}

\section{EXPERIMENTAL DATA}

During DSDP Leg 92, a series of holes were drilled at sites that form a west-east transect across the western flank of the East Pacific Rise at $19^{\circ} \mathrm{S}$ as part of an investigation of the region's hydrogeology (Fig. 2). Hole $597 \mathrm{C}$, a re-entry hole, was drilled $91 \mathrm{~m}$ into $28.6-\mathrm{Ma}$ basement that was generated at the now-extinct but fastspreading Mendoza Rise. Massive flows appear to comprise the entire sequence drilled. Of the material recovered, only one small fragment might possibly be a pillow margin (Site 597 chapter, this volume). Our confidence in this interpretation of the basalts is supported by both the BHTV amplitude records and the completeness of core recovery, which ranged up to $94 \%$ (see Fig. 3). The caliper logs indicate that the borehole has few abrupt changes in diameter (Site 597 chapter, this volume). Although the BHTV amplitude records for the basement are wavy, they show that the wellbore is generally uniform and solid in appearance and has few major zones of low reflectivity (Fig. 3).

The BHTV amplitude records for Hole 597C indicate that the zones of borehole breakout are oriented NNESSW. (Fig. 4A shows a reflectivity record of an interval $5 \mathrm{~m}$ long from Hole $597 \mathrm{C}$ that is oriented with respect to magnetic north. The vertical bands oriented NNE-SSW are breakout zones.) Because the wellbore is otherwise smooth and solid, breakouts are easy to recognize from cross-sections produced by the processing of traveltime data from the BHTV. Figure 4B shows a cross-section of the breakout at a depth of about $30 \mathrm{~m}$ into basement that was made by plotting the traveltime of the reflected acoustic pulse as a function of azimuth. In this study, each measurement of breakout orientation was made by using data from two rotations of the tool.

Eighteen measurements of breakout orientation were made from the BHTV records for the upper $50 \mathrm{~m}$ of 


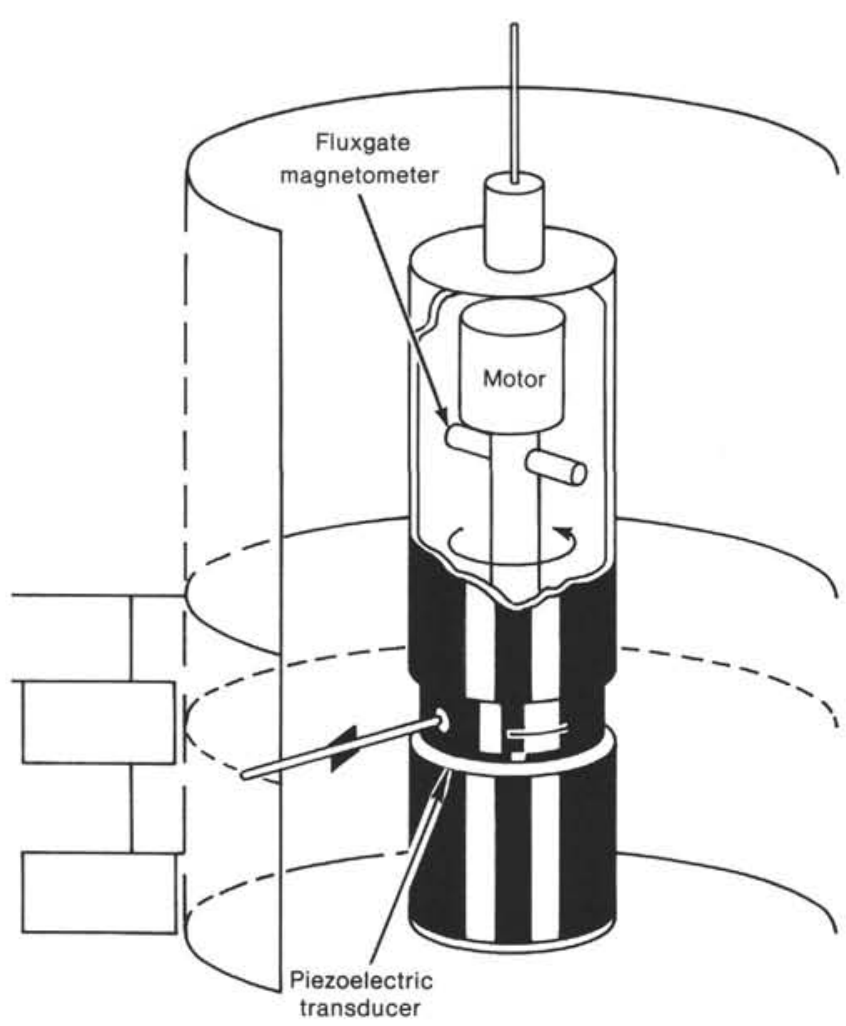

Figure 1. Schematic of the borehole televiewer. The televiewer contains a rotating piezoelectric transducer which emits and receives an ultrasonic pulse 600 times per revolution; it rotates 3 times per s. The amplitude of the reflected acoustic pulse, when plotted on a threeaxis oscilloscope as a function of beam azimuth and vertical position in the hole, produces an image of wellbore reflectivity, or smoothness. The traveltime of the reflected acoustic pulse, when plotted as a function of beam azimuth, produces a detailed crosssection of the wellbore. A fluxgate magnetometer triggers the scope trace at magnetic north so that the orientation of observed features can be determined. For a more detailed description of tool operation, see Zemanek et al. (1970). basement in Hole 597C. Examples of cross-sections of breakout zones in Hole 597C are shown in Figure 5A. In Figure 5B, the azimuths of the midpoints of each breakout zone are plotted versus depth. The mean elongation directions are $\mathrm{N} 30 \mathrm{E}$ and $\mathrm{N} 208 \mathrm{E} \pm 25^{\circ}$, with a mean separation of $178^{\circ}$. As a result, the average maximum horizontal compression direction is N121E magnetic, or N110E true.

\section{DISCUSSION}

Hole $597 \mathrm{C}$ is about $1800 \mathrm{~km}$ west of the East Pacific Rise, over $2000 \mathrm{~km}$ east of Tahiti, and over $4600 \mathrm{~km}$ from the Tonga-Kermadec Trench. Ridge push from the East Pacific Rise would produce west-northwest compression at the site. The net slab pull, or the sum of the driving and resisting slab forces due to subduction at the Tonga-Kermadec Trench, would produce west-northwest tension at the site. The directions of the principal horizontal stresses are compared with the directions of relative and absolute plate motion for the Pacific Plate in Figure 6. The direction of maximum horizontal compression at Site 597 is parallel to both the relative and absolute motion vectors for the Pacific Plate. This finding is consistent with the idea that a dominant ridgepush force is acting at the site.

The shaded areas in Figure 6 indicate the local range of uncertainty in identifying the $\mathrm{J}$ line, which is defined by Okal and Bergeal (1983) as the line that separates lithosphere generated at the Mendoza Rise (before a Miocene ridge jump that occurred about $20 \mathrm{Ma}$ ) from newer lithosphere generated at the East Pacific Rise. Because the ridge jump was accompanied by a change in the azimuth of spreading, the J line separates lithosphere with differing tectonic orientations. Fracture zones trend $\mathrm{N} 250 \mathrm{E}$ in the older lithosphere and N290E in the younger lithosphere.

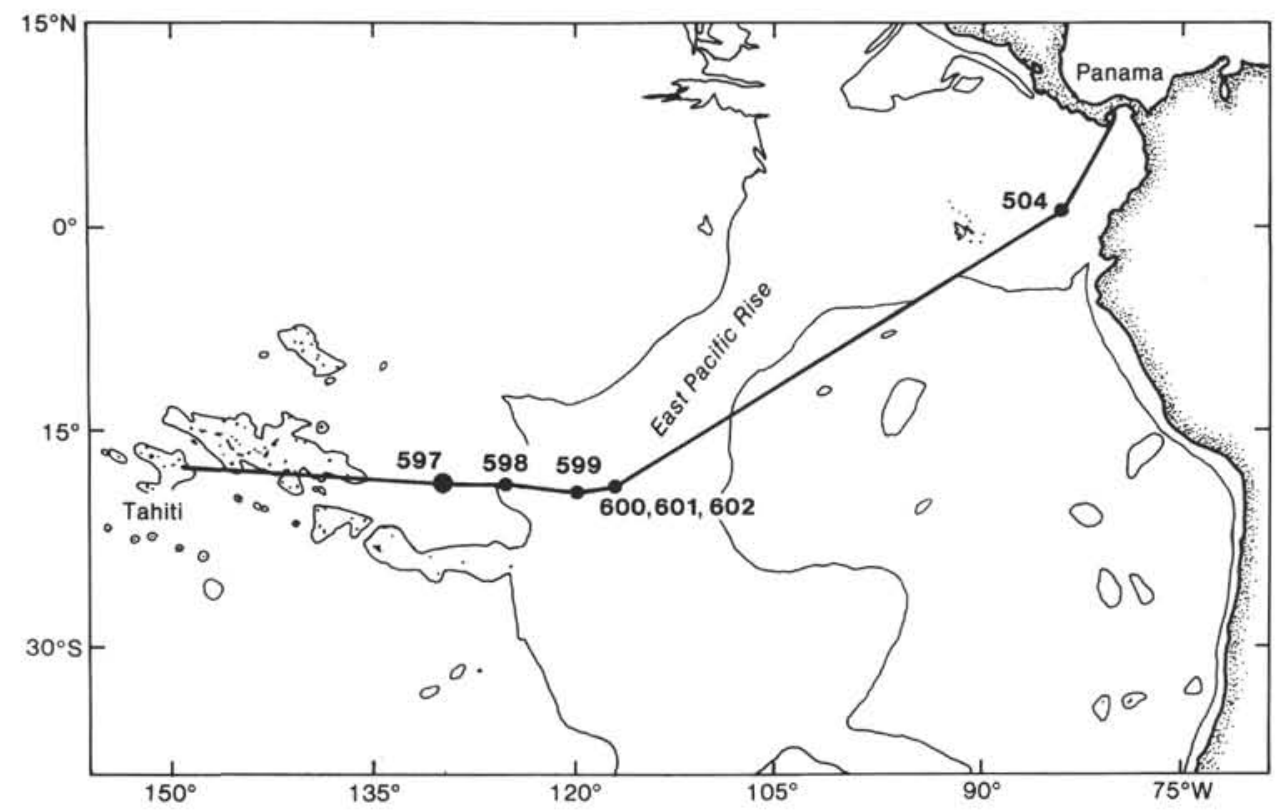

Figure 2. Location of Site 597 along ship track for Leg 92. 


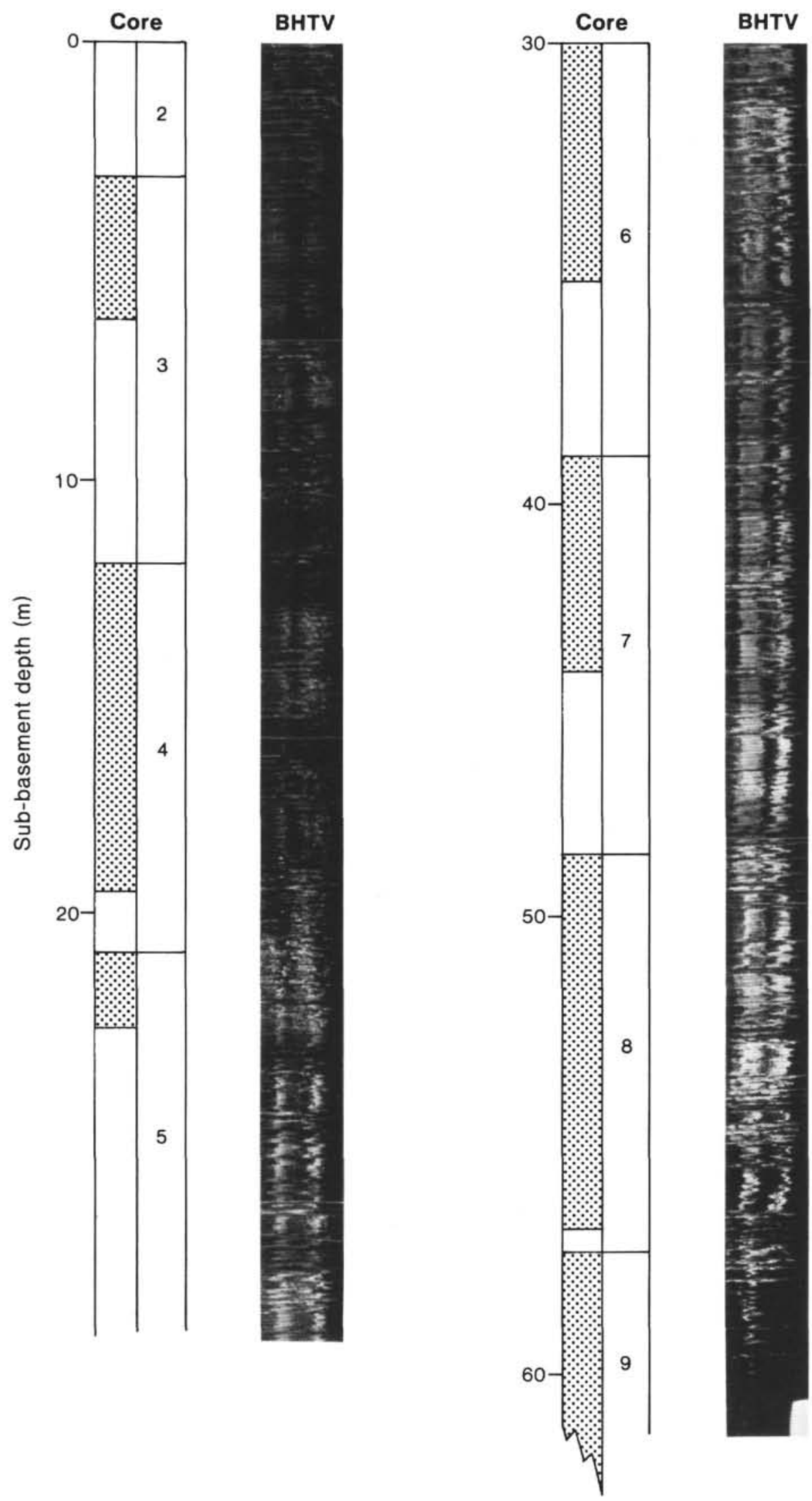

Figure 3. Borehole televiewer amplitude images obtained in Hole $597 \mathrm{C}$ correlated with coring intervals. The records are wavy as the result of changes in tool rotation speed. The stippled areas indicate the core recovery over an interval. The left and right edges of the data band are magnetic $\mathrm{N}$. 
A

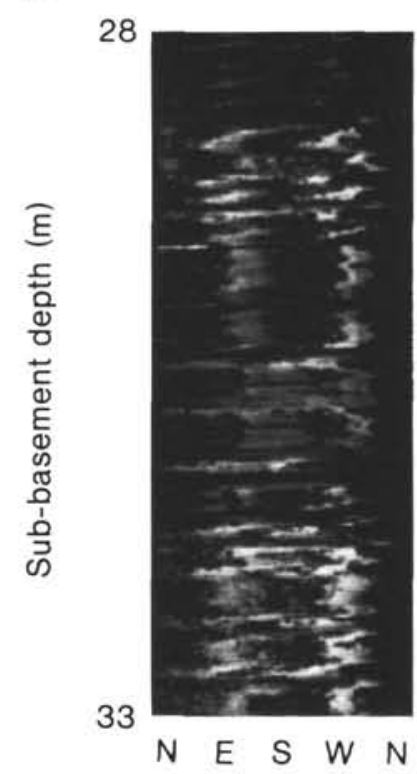

B

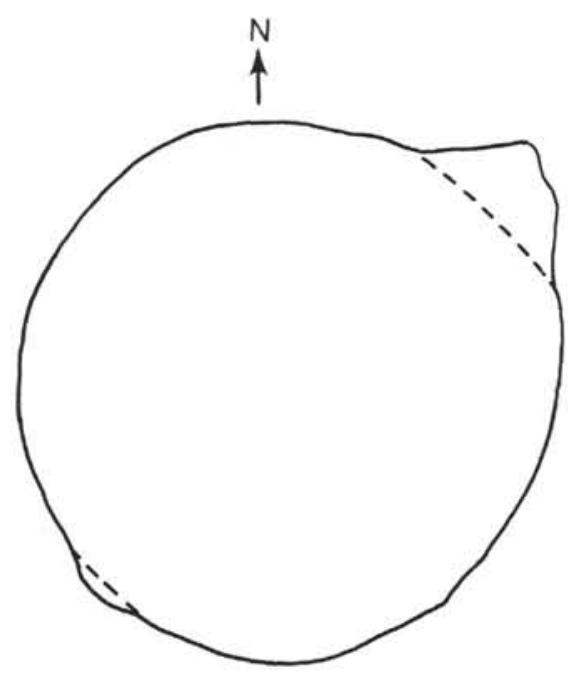

Figure 4. A. Amplitude, or plan-view borehole televiewer record of $5 \mathrm{~m}$ of Hole 597C. Width across image is about $1 \mathrm{~m}$. Dark vertical bands oriented NNE-SSW are breakout zones. B. Cross-section of Hole $597 \mathrm{C}$ at a depth of about $30 \mathrm{~m}$ into basement, showing breakout.

A
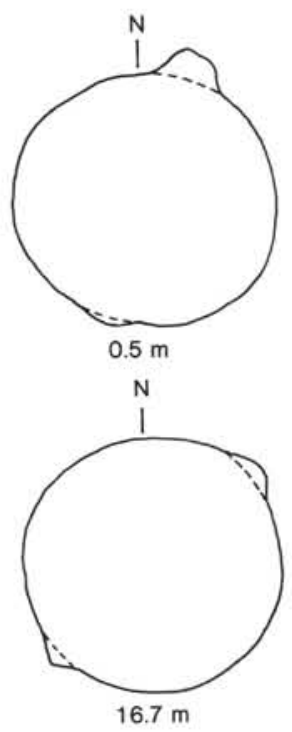
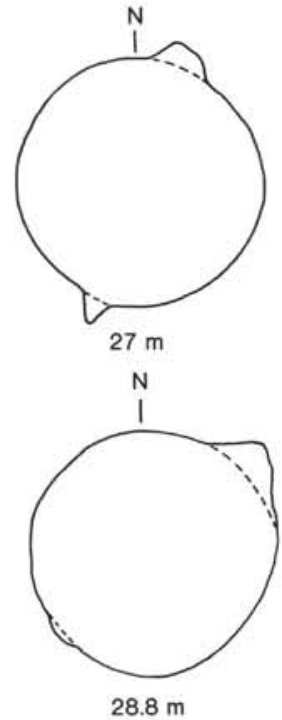

B

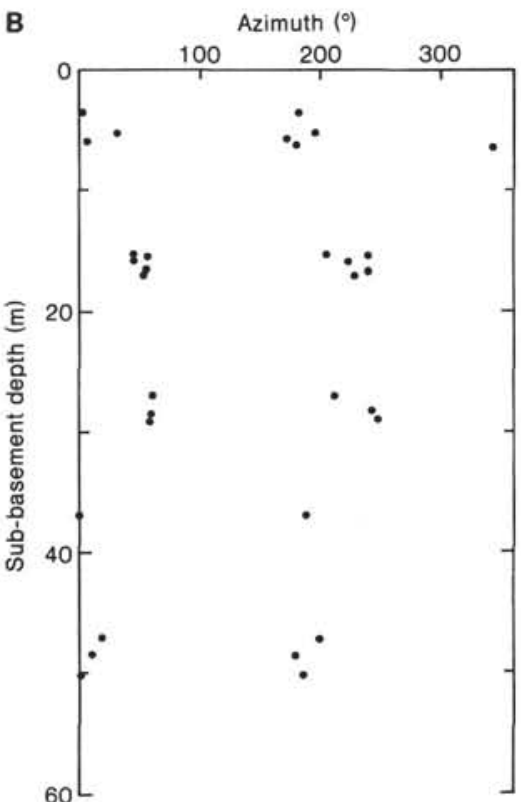

Figure 5. A. Examples of breakout cross-sections in Hole 597C. Depths are in meters sub-basement. Asymmetries in the cross-sections are probably caused by uneven enlargement of the breakout zones as a result of abrasion which has occurred after their formation. B. Azimuths (with respect to magnetic north) of the midpoints of borehole breakouts versus depth in Hole 597C. Mean azimuths are N30E and $\mathrm{N} 208 \mathrm{E} \pm 25^{\circ}$.

The intraplate seismicity in this area demonstrates a change in the nature of seismicity and the consistency of stress orientations inferred from intraplate earthquakes located in crust on either side of the $\mathrm{J}$ line. Focal mechanism solutions of several intraplate earthquakes located in the general vicinity of Site 597 are shown in Figure 6, and relevant data pertaining to these and other events are listed in Table 1. These mechanisms are taken from Okal et al. (1980), Okal (1984), Dziewonski and Woodhouse (1983), Bergman and Solomon (1984), and Wiens and Stein (1984).

Sites 11, 10, and 7 in Figure 6 correspond to Okal et al.'s (1980) regions A, B, and C, respectively. Each of these sites is the location of a cluster of earthquakes and 


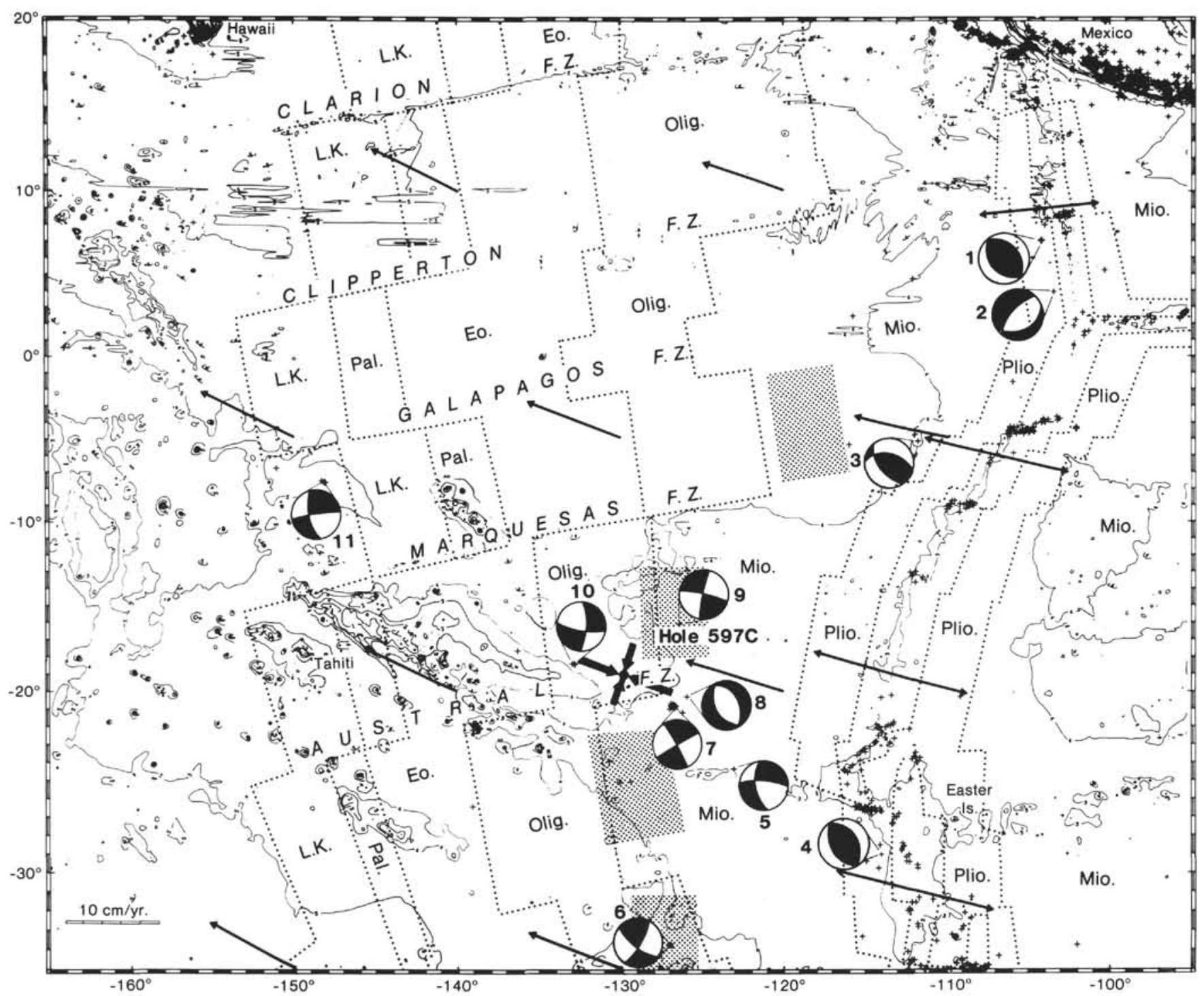

Figure 6. Stresses near Hole 597C. Heavy arrows indicate the principal horizontal stress directions determined from breakout directions at Hole 597C. Light single-headed arrows indicate the absolute Pacific Plate motion, and light double-headed arrows show relative Pacific-Nazca Plate motion (Minster and Jordan, 1978). The trend of the East Pacific Rise is shown by crosses, which mark the locations of earthquakes that had a body-wave magnitude $>4.5$ and were recorded by more than 10 stations by the ISC between 1963 and 1979 (Haxby and Weissel, in press). Seafloor age is shown. Focal mechanism solutions are discussed in the text (Table 1).

has a horizontal dimension of $50 \mathrm{~km}$ or less. All solutions of earthquakes located in these clusters indicate focal depths of $5 \mathrm{~km}$ or less.

A seismic network in French Polynesia has provided a detailed account of the seismicity in these regions over the past several years (Okal et al., 1980), of which the following is a summary:

At Site 11, activity is characterized by swarms, mostly with strike-slip solutions with some normal component. The $\mathrm{P}$ axes are oriented WNW-ESE, a direction that is nearly parallel to both the current relative and absolute plate motion vectors. There is no evidence of related local bathymetric features.

At Site 10, activity occurred as discrete events through time, again mostly characterized by strike-slip solutions with some normal component. There were 12 events with a body-wave magnitude up to 5.5 over $15 \mathrm{yr}$.

At Site 7, there was a 3-yr. swarm of intense activity between 1976 and 1979, with over 96 events; they are characterized primarily by strike-slip solutions, but, unlike the activity at Sites 10 and 11 , have some thrust component. This swarm was followed by a 3-yr. period of quiescence with no activity of magnitude $>4$. In July of 1983, a mainshock-aftershock pair of events occurred only $65 \mathrm{~km}$ away (at Site 8 ). These events had a purely normal solution and a focal depth of 15 to $20 \mathrm{~km}$. There is no evidence of a related local bathymetric feature in the area.

Site 5 is the location of a normal faulting event with a body-wave magnitude of 6.8 , one of the largest normal 
Table 1. Focal mechanism data.

\begin{tabular}{lrccccc}
\hline Site & $\begin{array}{c}\text { Event } \\
\text { date }\end{array}$ & $\begin{array}{c}\text { Event location } \\
\left({ }^{\circ} \mathrm{N},{ }^{\circ} \mathrm{W}\right)\end{array}$ & $\begin{array}{c}\text { Body-wave } \\
\text { magnitude }\end{array}$ & $\begin{array}{c}\text { P axis } \\
\text { (strike, dip) }\end{array}$ & Type $^{\mathrm{a}}$ & Reference $^{\mathrm{b}}$ \\
\hline 1 & $1-21-70$ & $7.02,104.30$ & 6.2 & 50,4 & $\mathrm{~T}$ & 1 \\
1a & $9-11-75$ & $6.99,104.28$ & 6.4 & 67,73 & $\mathrm{~T}$ & 1 \\
2 & $10-29-75$ & $3.92,103.61$ & 5.5 & 130,68 & $\mathrm{~N}$ & 1 \\
3 & $9-30-81$ & $-5.09,111.98$ & 5.9 & 205,4 & $\mathrm{~T}$ & 2 \\
4 & $4-18-82$ & $-29.07,113.84$ & 5.9 & 57,2 & $\mathrm{~T}$ & 3 \\
5 & $11-22-55$ & $-24.50,123.00$ & 6.8 & 136,49 & $\mathrm{~N}$ & 4 \\
6 & $9-14-63$ & $-33.60,126.70$ & 4.9 & 80,2 & $\mathrm{SS}$ & 4 \\
7 & $7-25-78$ & $-20.14,126.94$ & 5.4 & 107,0 & $\mathrm{SS}$ & 5 \\
8 & $7-31-83$ & $-20.14,125.87$ & 6.0 & 60,85 & $\mathrm{~N}$ & 5 \\
9 & $7-30-78$ & $-16.23,126.94$ & 5.0 & 236,3 & $\mathrm{SS}$ & 5 \\
10 & $9-18-66$ & $-18.48,132.81$ & 5.0 & 324,33 & $\mathrm{SS}$ & 5 \\
$10 \mathrm{a}$ & $3-6-65$ & $-18.40,132.90$ & 5.5 & 305,31 & $\mathrm{SS}$ & 5 \\
$10 \mathrm{~b}$ & $5-25-75$ & $-18.40,132.80$ & 5.0 & 335,23 & $\mathrm{SS}$ & 5 \\
11 & $8-6-69$ & $-7.36,148.38$ & 5.1 & 104,23 & $\mathrm{SS}$ & 5 \\
$11 \mathrm{a}$ & $7-29-68$ & $-7.50,148.3$ & 4.9 & 97,11 & $\mathrm{SS}$ & 5 \\
$11 \mathrm{~b}$ & $1-19-73$ & $-7.40,148.30$ & 4.9 & 116,21 & $\mathrm{SS}$ & 5 \\
$11 \mathrm{c}$ & $1-19-73$ & $-7.3,148.30$ & 4.9 & 131,28 & $\mathrm{SS}$ & 5 \\
\hline
\end{tabular}

a $\mathrm{T}=$ thrust, $\mathrm{N}=$ normal, $\mathrm{SS}=$ strike-slip.

b $1=$ Wiens and Stein, 1984; 2 = Dziewonski and Woodhouse, 1983; 3 = Dziewonski et al., 1983; $4=$ Okal et al., 1980; $5=$ Okal, 1984.

faulting events known in young oceanic lithosphere. The epicenter of the event lies NW of a major seamount, to which this activity is probably related.

Site 6 is within the range of uncertainty of the J line's location.

The focal mechanism solutions of earthquakes located in older crust (Sites 10 and 11) indicate a P axis orientation of WNW-ESE, a direction consistent with the idea that a dominant ridge-push force is acting on the plate (Fig. 7) (Table 1). However, events located at sites near the $\mathrm{J}$ line or on younger crust show more diverse $\mathrm{P}$ axis orientations (Fig. 7) (Table 1). At Sites 7 and 8, events occur with normal, thrust, and strike-slip mechanisms within $3 \mathrm{yr}$ and $65 \mathrm{~km}$.

Site 597 is located in crust about 8.5 m.y. older than the $\mathrm{J}$ line and indicates a dominant stress orientation that is consistent with the stress regime inferred by the intraplate events in older crust. Sbar et al. (1984) have shown that reliable measurements of contemporary tectonic stress can be made near the surface; in their study of near-surface in situ stress in southern California, it was determined that measurements made below a depth of $6 \mathrm{~m}$ produced reliable observations of contemporary tectonic stress. The agreement between the principal horizontal stress directions determined by using breakouts in Hole 597C and the state of stress inferred from the intraplate earthquakes located in the older crust of the $\mathrm{Pa}$ cific Plate is encouraging, inasmuch as our measurement is made in only the upper $50 \mathrm{~m}$ of the oceanic crust.

Most events far from plate boundaries indicate compressive stresses that are thought to result from the gravitational force due to lithospheric thickening with age, or ridge-push force. However, both compressional and extensional events occur in young lithosphere. A number of authors (e.g., Sykes and Sbar, 1973; Wiens and Stein, 1985) have proposed ages of from 10 to $35 \mathrm{~m}$.y. for the transition between the near-ridge tectonic regime, which may be dominated by local forces, and the stress regime in stable plate interiors, which is characterized by horizontal compression. It appears from the earth-

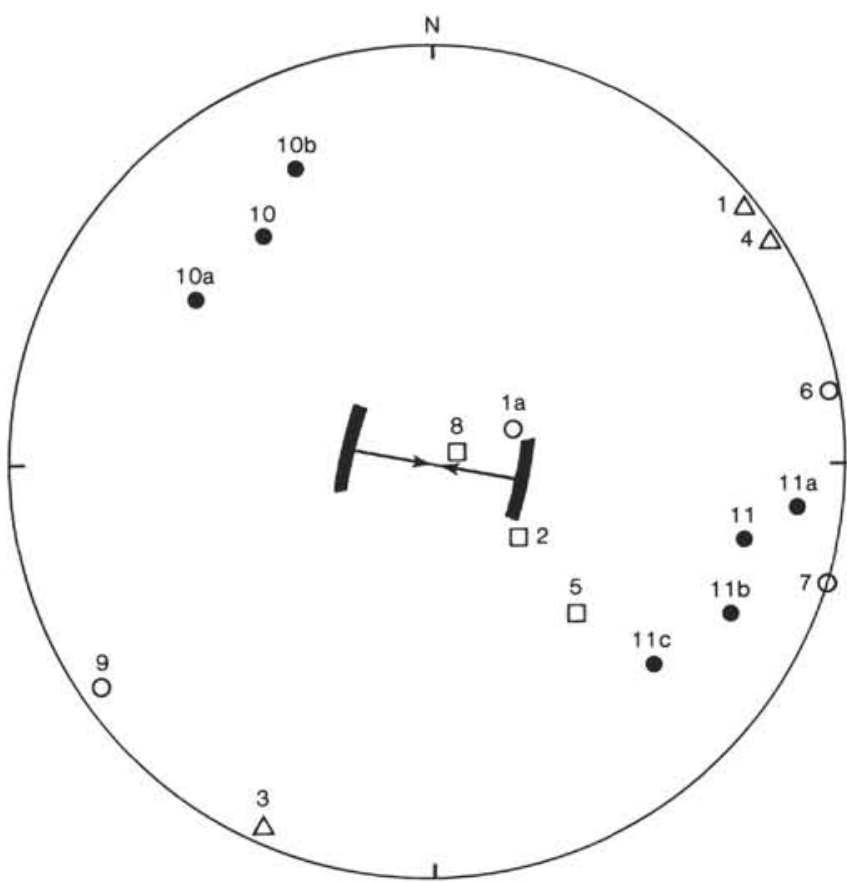

Figure 7. Stereographic projection of lower focal hemisphere, showing $P$ axes for mechanisms listed in Table 1. Triangles represent thrust; circles, strike-slip; and squares, normal mechanisms. Solid symbols represent mechanisms for earthquakes that occur in crust generated at the Mendoza Rise, open symbols for those which occur in crust generated at the East Pacific Rise. Arrows and error bars indicate the orientation of principal horizontal stress determined from borehole breakouts in Hole 597C.

quake data that Site 597 is located very close to this transition zone west of the East Pacific Rise.

To date, two in situ measurements of principal stress orientations have been made in DSDP holes: at Hole 504B, south of the Costa Rica Rift on the Nazca Plate (Newmark et al., 1984 and 1985), and here at Hole 597C on the Pacific Plate. In both cases, the orientation of in situ principal stresses determined from borehole breakouts has been consistent with the stress directions inferred from intraplate earthquakes near the sites. The major importance of this work is the demonstration that stress orientations can be reliably determined from borehole breakouts in the oceanic crust. With the advent of a new phase of deep ocean drilling, we are confident that these measurements, routinely made in boreholes at locations oriented with respect to major plate boundaries, will allow us to more clearly define the state of stress in the upper oceanic crust and the relationships between the driving forces of plate tectonics.

\section{ACKNOWLEDGMENTS}

We would like to thank the officers, crews and scientific party of Glomar Challenger on Leg 92, without whose diligence and hard work the televiewer logs could not have been successfully completed. We would also like to thank the French Navy, particularly the officers and crew of the Papanoo, for making possible our participation in Leg 92. Larry Mastin and Gray Jensen at the U.S.G.S. provided invaluable technical assistance. We also thank Chris Scholz, Keith Evans, Emil Okal, Sean Solomon, and two anonymous reviewers for constructive 
comments on the manuscript. This work was supported by National Science Foundation Grant OCE 81-10919 and Office of Naval Research Contracts TO-0098 and TO-0132, scope HH.

\section{REFERENCES}

Babcock, E. A., 1978. Measurement of subsurface fractures from dipmeter logs. A.A.P.G. Bull., 62:1111-1126.

Bell, J. S., and Gough, D. I., 1979. Northeast-southwest compressive stress in Alberta: evidence from oil wells. Earth Planet. Sci. Lett., $45: 475-482$.

1982. The use of borehole breakouts in the study of crustal stress. Workshop on Hydraulic Fracturing Stress Measurements. U.S.G.S. Open-File Report, 82-1075:539-557.

Bergman, E. A., and Solomon, S. C., in press. Source mechanisms of earthquakes near mid-ocean ridges from body waveform inversions: implications for the early evolution of oceanic lithosphere. J. Geophys. Res, 89:11, 415-11,441.

Blumling, P., Fuchs, K., and Schneider, T., 1983. Orientation of the stress field from breakouts in a crystalline well in a seismic active area. Phys. Earth Planet. Inter., 33:250-254.

Brown, R. O., Forgotson, J. M., and Forgotson, J. M., Jr., 1980. Predicting the orientation of hydraulically created fractures in the Cotton Valley Formation of east Texas. Soc. Petrol. Eng. 55th Annu. Mtg. (Dallas), Paper SPE 9269.

Cox, J. W., 1970. The high resolution dipmeter reveals dip-related borehole and formation characteristics [paper presented at the Eleventh Annu. Symp. Soc. Prof. Well Log Anal., Los Angeles, CA].

Dziewonski, A. M., Friedman, A., Giardini, D., and Woodhouse, J. H., 1983. Global seismicity of 1982: centroid-moment tensor solutions for 308 earthquakes. Phys. Earth Planet. Inter. 33:76-90.

Dziewonski, A. M., and Woodhouse, J. H., 1983. An experiment in systematic study of global seismicity: centroid-moment tensor solutions for 201 moderate and large earthquakes of 1982. J. Geophys. Res., 88:3247-3272.

Fordjor, C. K., Bell, J. S., and Gough, D. I., 1983. Breakouts in Alberta and stress in the North American Plate. Canad. Jour. Earth Sci., 20:1445-1455.

Gough, D. I., and Bell, J. S., 1981. Stress orientations from oil-well fractures in Alberta and Texas, Can. J. Earth Sci., 18:638-645.

, 1982. Stress orientations from borehole wall fractures with examples from Colorado, east Texas, and northern Canada. Can. J. Earth Sci., 19:1358-1370.

Gough, D. I., Fordjor, C. K., and Bell, J. S., 1983. A stress province boundary and tractions on the North American Plate. Nature (London), 305:619-621.

Haxby, W. F., and Weissel, J. K., 1985. Evidence for small-scale mantle convection from SEASAT altimeter data. J. Geophys. Res., 91: $3507-3520$.

Hickman, S. H., Healy, J. J., Zoback, M. D., Svitek, J. F., and Bretcher, J. E., 1982. In situ stress, borehole elongation, and natural fracture distribution, at depth in central New York State. EOS, Trans. Am. Geophys. Union, 63:1118.

Minster, J. B., and Jordan, T. H., 1978. Present-day plate motions. J. Geophys. Res., 83:5331-5354.
Newmark, R. L., Zoback, M. D., and Anderson, R. N., 1984. Orientation of in situ stresses in the oceanic crust. Nature (London), 311:424-428.

1985. Orientation of in situ stresses near the Costa Rica Rift and Peru-Chili Trench: Deep Sea Drilling Project Hole 504B. In Anderson, R. N., Honnorez, J., Becker, K., et al., Init. Repts. DSDP, 83: Washington (U.S. Govt. Printing Office), 511-515.

Okal, E. A., 1984. Intraplate seismicity of the southern part of the Pacific Plate. J. Geophys. Res., 89:10,053-10,071.

Okal, E. A., and Bergeal, J.-M., 1983. Mapping the Miocene Farallon ridge jump on the Pacific Plate: a seismic line of weakness. Earth Planet. Sci. Lett., 63:113-122.

Okal, E. A., Talandier, J., Sverdrup, K. A., and Jordan, T. H., 1980. Seismicity and tectonic stress in the Southcentral Pacific. J. Geophys. Res., 85:6479-6495.

Plumb, R. A., 1982. Breakouts in the geothermal well, Auburn, N. Y. EOS, Trans. Am. Geophys. Union, 63:1118.

Sbar, M. L., Richardson, R. M., Flaccus, C., and Engelder, E., 1984. Near-surface in situ stress: 1 . Strain relaxation measurements along the San Andreas fault in southern California. J. Geophys. Res., 89:9323-9332.

Schafer, J. N., 1980. A practical method of well evaluation and acreage development for the naturally fractured Austin Chalk formation. The Log Analyst, 21:10-23.

Seeburger, D. A., and Zoback, M. D., 1982. The distribution of natural fractures and joints at depth in crystalline rock. J. Geophys. Res., 87:5517-5534.

Springer, J. E., and Thorpe, R. K., 1981. Borehole elongation versus in situ stress orientation. Internat. Conf. on In Situ Testing of Rock and Soil Masses (Santa Barbara, Jan. 4-8, 1982), Paper UCRL87018.

Sykes, L. R., and Sbar, M. L., 1973. Intraplate earthquakes, lithospheric stresses and the driving mechanism of plate tectonics. $\mathrm{Na}$ ture (London), 245:298-302.

Wiens, D. A., and Stein, S., 1985. Implication of oceanic intraplate seismicity for plate stresses, driving forces and rheology. Tectonophysics, 116:143-162.

, 1984. Intraplate seismicity and stresses in young oceanic lithosphere. J. Geophys. Res., 89:11,442-11,464.

Zemanek, J., Glen, E. E., Jr., Norton, L. J., and Cardwell, R. L., 1970. Formation evaluation of inspection with the borehole televiewer. Geophysics, 35:254-269.

Zoback, M. D., and Anderson, R. N., 1982. Ultrasonic borehole televiewer investigation of oceanic crustal layer $2 \mathrm{~A}$, Costa Rica Rift. Nature (London), 295:375-379.

Zoback, M. D., Moos, D., Mastin, L., and Anderson, R. N., 1985. Well bore breakouts and in situ stress. J. Geophys. Res., 90:55235530 .

Date of Initial Receipt: 16 July 1984

Date of Acceptance: 4 January 1985 